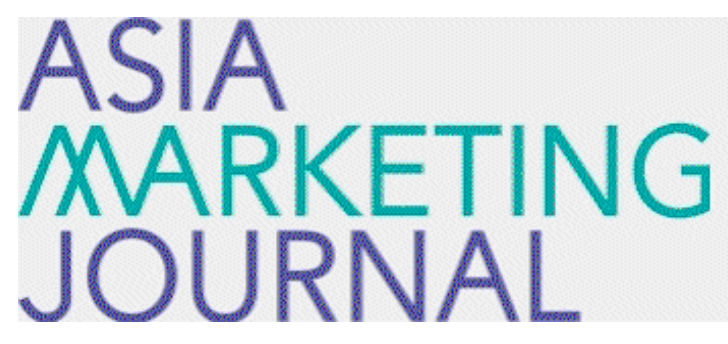

ASIA MARKETING JOURNAL

Volume 1 | Issue 3

Article 4

6-1-1999

\title{
Understanding Service Quality in Health / Fitness Clubs from A Systems Perspective
}

Kyung Ro Chang

Follow this and additional works at: https://amj.kma.re.kr/journal

Part of the Marketing Commons

\section{Recommended Citation}

Chang, Kyung Ro (1999) "Understanding Service Quality in Health / Fitness Clubs from A Systems Perspective," Asia Marketing Journal: Vol. 1 : Iss. 3 , Article 4.

Available at: https://doi.org/10.53728/2765-6500.1018

This Article is brought to you for free and open access by Asia Marketing Journal. It has been accepted for inclusion in Asia Marketing Journal by an authorized editor of Asia Marketing Journal. 


\title{
Understanding Service Quality in Health/Fitness Clubs from A Systems Perspective
}

\author{
Kyungro Chang \\ (Iowa State University changk@iastate.edu)
}

\begin{abstract}
Despite of the vibrant nature of the fitness industry, there has not been a sustained effort to understand the dynamics of the industry, particularly with reference to the quality of services offered in that industry. The purpose of this paper is to present a system based process model of quality in health/fitness services. The characteristics of the organization, the service employees and the client are the inputs into the service encounter where the service is produced (i.e., the throughput). The output is the quality of the service. The extent of quality perceived by both the service provider and the client is said to influence the satisfaction of the respective parties, and subsequent motivation to participate in the production of quality in the service. The model also suggests that physical environment as well as other customers and their behaviors influence customer perception of service quality. The quality of service is enhanced through the quality assurance practices of the organization and the feedback from client. Further, the input, throughput, and output in our model reflect (a) quality of the design of the service delivery system, (b) objective quality of the product, and (c) quality as perceived by client. The specific attributes of the design element (i.e., organization, service employee, and the client) are elaborated upon. It is suggested that the organization can assure quality by seeking feedback from clients and service employees, monitoring the service production phases, and managing inter-customer interactions.
\end{abstract}




\section{Understanding Service Quality in Health/Fitness Clubs from A Systems Perspective}

The service industry has been expanding and recent reports have indicated that the service sector accounts for almost $80 \%$ of all jobs in business industry (Henkoff, 1994). Consistent with the above trend, the type and number of organizations offering services in sport and leisure have also grown dramatically. Apart from the sporting goods manufacturing industry, virtually all products in the sport industry are services.

Although sport management has made extraordinary strides on both the academic and professional fronts, it is surprising that the study of sport and leisure services and their quality has been limited. This is particularly true in the case of health/fitness service organizations, which are sprouting everywhere. There has been an enormous growth in the fitness/health club industry. The phenomenal growth in the health/fitness club industry is attributed to the increase awareness by the public of the benefits of exercise on their health. Customers are becoming more knowledgeable about fitness, and healthful lifestyles. As the industry is maturing, competition is increasing and becoming more sophisticated. Thus, the success of a club in the competitive business will be determined by how well the club provides quality services to members. Despite the rapid growth of this industry, little is known about the management of the operations in individual enterprises.

One approach to the study of services and their quality is to view the production and consumption of a service from a systems perspective. Lovelock (1996) suggests that

Any service business can be thought of as a system comprising service operations, where inputs are processed and the elements of the service product are created, and service delivery, where final assembly of these elements takes place and the product is delivered to the customer (p. 
$52)$.

As quality in services is generated through the interaction of products/services, people, processes, and environments, the identified target should encompass the contributions of the three significant parties to the transaction - the organization, the service provider, and the client. This notion becomes central to those service operations where the clients are in close contact with all three elements in receiving the service. The role of the interaction of products/services, people, processes, and environments is best understood if the production and consumption of a service are viewed from a systems perspective. Scholars have argued that the notions advanced by proponents of quality and Total Quality Management (TQM) are consistent with conceptualization of organizations as open systems (e.g., Cusins, 1994;

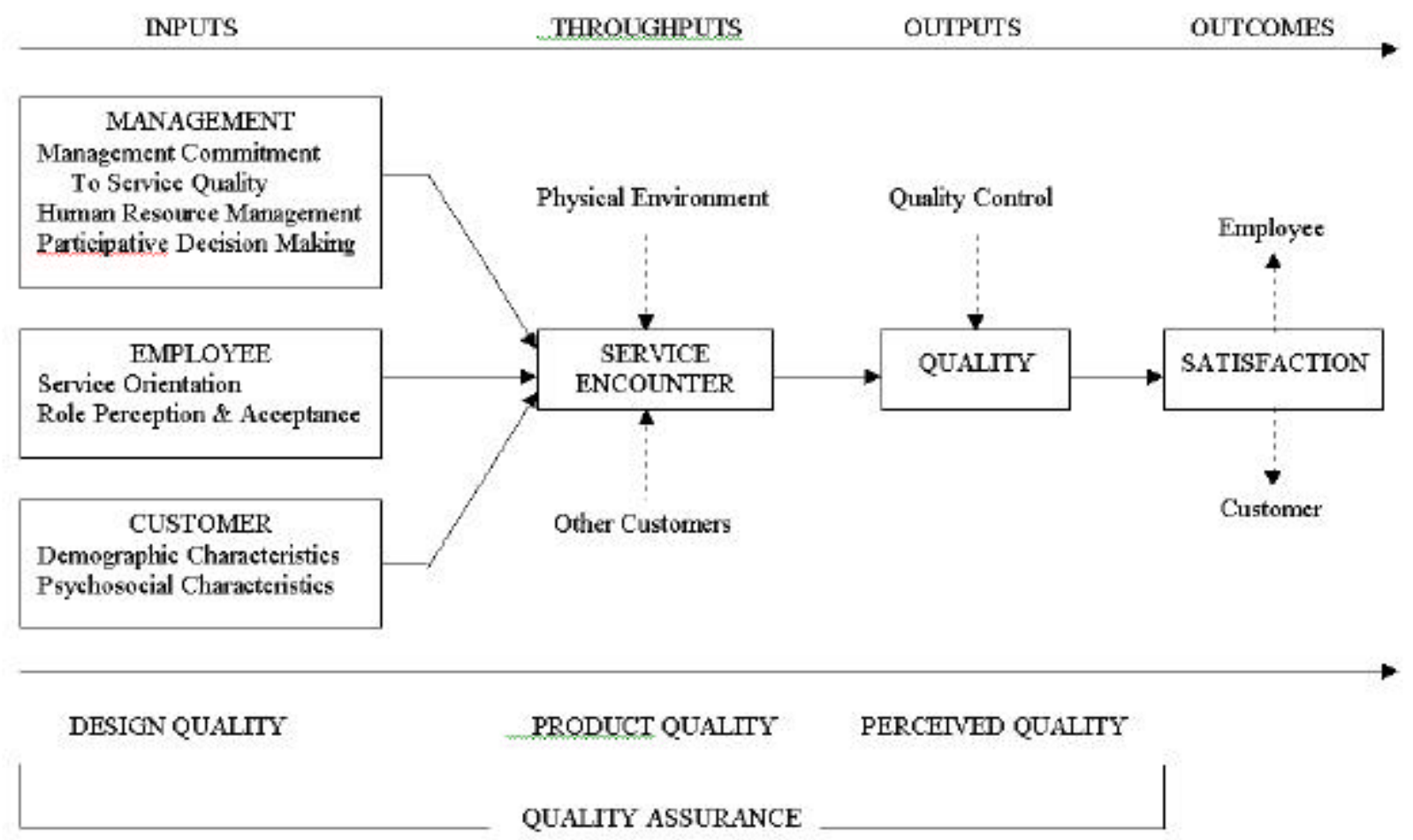

Figure 1. The System Model of Achicving Quality in Health/Fitness Services 
Lengnick-Hall, 1996; Spencer, 1994).

Fitness clubs are example of organizations wherein the clients are central to the service operations. As fitness clubs are relatively smaller, the clients have greater opportunities to understand the organization and its management. In addition, the clients are in contact with the service employees more frequently and for longer periods of time than in conventional service organizations. Finally, as fitness clubs serve more than one customer at a time, a client is in interaction with other clients. Thus, judgements of service quality would not be confined to the end result of the production process. Instead, client evaluations of quality are made not only on the outcome of a service but also on the process of service delivery (Bowen \& Schneider, 1988; Johnson, Tsiros, and Lancioni, 1995).

Following the above line of reasoning, the purpose is to present a system based model of quality in fitness services as shown in Figure 1. More specifically, management, service employee, and clients are perceived to bring their orientations and attributes as inputs into the system. The interactions of employee and clients in a given physical environment (i.e., the service encounter) constitute the throughput stage of the system. The output stage of the system is the quality of the service provided. Finally, the satisfaction of both the client and employee are said to be the outcomes. The stages of the proposed system are elucidated in the following sections.

\section{THE INPUTS}

All systems are dependent on some inputs for generating the activities that will ultimately result in goal attainment. Those inputs in an organization may vary from raw materials to specific tasks performed by people. One of the major tasks in developing services is to build in the right quality from 
the start (Edvardsson \& Olsson, 1996). That is, quality of a service is dependent on the mix of inputs from management, employees, and customers.

\section{Management Inputs}

An essential feature of Total Quality Management (TQM) is to ensure the input of necessary competencies and the creation of a service climate which in turn is a function of the values held by management (Dickens, 1994). Theorists have suggested that quality should be built-in early at the development and/or design stage (e.g., Edvardsson, Thomasson, \& Ovretveit, 1994). That is, management' s contributions at the input stage go a long way in determining the quality of services.

In service-related research, it is argued that characteristics of management such as (a) commitment to quality, (b) human resource management, and (c) participative decision making process are systematically associated with employee and customer perceptions of service quality (e.g., Schneider, wheeler, \& Cox, 1992; Zeithaml, Berry, \& Parasuraman, 1988). These management characteristics are said to create a unique climate for the delivery of services, the service climate. According to Schneider (1990) service climate is reflected in employees' perceptions that (a) practice and procedures were in place to facilitate the delivery of excellent service, and (b) management rewarded, supported, and expected excellent service.

Management commitment to quality. Ahmed and Parasuraman (1994) defined management commitment to service quality as "encompassing the conscious choice of quality initiatives as operational and strategic options for the firm, and engaging in activities such as providing visible quality leadership and resources for the adoption and implementation of quality initiatives." (p. 85) Although management 
commitment to quality has been linked to perceptions of service quality, all too often service firms take a product-based approach and cost-reduction strategies o maximize short-term profits (Garvin, 1983; Zeithaml et al., 1988). Clearly, such a product-centered approach could have negative ramifications on employee attitudes and perceptions of service quality. In contrast, organizations should be customeroriented by recognizing the critical importance of the customers and doing everything possible including soliciting their opinions to retain their business (Beatty, 1988). Operationally, this value stresses customer satisfaction and puts the customer in the center of the firm's decision-making efforts. In a service industry like a health/fitness club, customer opinions and perceptions are valuable tools for informing the managers what they are doing right and wrong, what needs improvement, and what they would like to see in the future. For these reasons, the customer must be the driving force behind management commitment to quality.

Human resource management. Schneider and Bowen (1985) have shown that when employees reported positively about how well they were trained, supervised, and so on, their customers also had favorable views of the quality of services they received. That is, employees have a tendency to treat others as they have been treated, thus customer contact employees who are treated as valuable persons by the organization will treat the organization's customers similarly (Schneider \& Bowen, 1995). In so far as the interaction between a service employee and a customer largely determines customer experiences, creating employee-oriented climate is equally important to ensure service quality. This orientation stresses human resource development, communication between managers and employees, and commitment to and respect for employee (Beatty, 1988). Schneider et al. (1992) suggested that organizations should have human resource practices (e.g., selection, training, and reward systems) that are compatible with providing high service quality. 
Participative decision making. Due to the unique characteristics of service firms, it is necessary to involve front-line employees in the decision making process. Research has shown that employee participation enhances job satisfaction and productivity, reduces role ambiguity and role conflict (Jackson, 1983). Further, participation in task relevant decisions is said to enhance the acceptance of those decisions by participants. In so far as the service providers participate in decisions, they are likely to accept the decisions and take ownership of those decisions. Therefore, they will implement them more effectively. It seems appropriate then to suggest that organizations concerned with quality should engage the front-line employees, the service providers, in decision making which affect their operations.

\section{$\underline{\text { The Service Employee Inputs }}$}

As employees of a service operation are in constant contact with customers of the business, they become an integral part of the image that a customer has of the business. Thus, the attributes they bring to the service encounter would have an impact on the production of a service and the quality thereof. While the most obvious characteristics are age, education, and experience, personality and attitudinal characteristics also have a great impact (Hogan, Hogan, \& Busch, 1984; Zeithaml et al., 1988). More specifically, service-orientation and role perception and role acceptance are emphasized in this paper.

Service orientation. Hogan et al. (1984) have defined service orientation as "a set of attitudes and behaviors that affects the quality of interaction between.... the staff of any organization and its customers." (P.167). Some of the characteristics associated with service orientation include elements of 
good adjustment, likability, social skill, and willingness to follow rules. Service-oriented employees (a) take an interest in their customers, (b) do more for the customers, (c) are more courteous and flexible, (d) try to find appropriate solutions to customers' wishes, and (e) go out of their way to recover a situation where something has gone wrong or unexpected situation has occurred (Gronroos, 1990). Thus, the service orientation of employees contributes to both the quality of service and the overall performance of the firm as a business enterprise.

$\underline{\text { Role Perception and Role Acceptance. }}$ Role ambiguity occurs when an employees do not possess sufficient information to perform their roles adequately (Rizzo, House, \& Lirtman, 1970). The degree to which the service providers perceive more ambiguity regarding the roles, the less effective they will be in enacting their roles. Role conflict occurs when the expectations and demands from two sources are incompatible and the individual perceives that these conflicting role expectations cannot be met simultaneously (Rizzo et al., 1970). This incompatibility can stem from conflict between (a) an individual's personal values and role expectations, (b) an individual's time/ resource and role expectations, (c) different roles for the same individual, and (d) policies, requests from others, and performance standards on the one hand and an individual's role expectations on the other. In addition, service employees as boundary spanners may be faced with conflicting demands posed by customer preferences and supervisor expectations.

The negative effects of role conflict and role ambiguity on individual and organization- al performance have been widely documented (Babin \& Boles, 1996). Primarily, role conflict and role ambiguity produce a state of psychological stress or tension that leads to diminished efforts, satisfaction, and performance, and thus the diminished quality of the service delivered (Zeithaml et al., 1988). We noted earlier that organizational practices, particularly participative decision making, clarifies the roles 
for the service providers, enhances their understanding of the decisions, and creates a sense of ownership in those decisions.

\section{$\underline{\text { Client Inputs }}$}

As customers get involved in the production of a service, they influence the service operations and outcomes of an enterprise (Lengnick-Hall, 1996). Different types of services have differing features of client involvement. That is, the inclusion of clients into the process of service production varies considerably depending not only on the type of service, but also on task requirements within a given service situation and the client's skills/knowledge and motivation level (Mill \& Morris, 1986). In a health/fitness club, clients are also performing complex activities in the rendering of their own services such as checking in, using locker room, operating equipment, etc. Further, when experienced customers help the new customers with, for example, operating exercise equipment they are enhancing the quality of the services offered by the enterprise. As customers' expertise increases, their ability to make effective contributions to production activities also increase (Lengnick-Hall, 1996).

As in the case of service providers, clients also bring their individual characteristics to the service encounter including gender, age, disability, and level of health/fitness. The service provider in health/fitness needs to determine the appropriateness of the services provided, and the processes of delivering them. For example, a fitness class designed for youthful clients will not be appropriate to the elderly clients. Similarly, an aerobics class for the fit and healthy may be unsuitable for overweight clients.

In addition to these physical and biological variations, clients may also differ in their personality traits, needs, and attitudes. These psychosocial differences will influence the nature of 
interpersonal interactions between the service provider and the client. In so far as a productive and pleasant service encounter is dependent on the interplay of psychosocial characteristics of persons in the encounter, individual differences would have direct effect on the quality of service. For example, the trait "negative affectivity" which is defined as a tendency to perceive everything (including people, events, and objects) in particular ways that lead to negative emotional state not be conducive for an effective service encounter, and production of quality service.

Although customer participation as co-producers of services for themselves is well documented, customers' role in producing services for other customers is less well under-stood. As noted earlier, customers with expertise and experience in the service encounter can and frequently do assist other customers as much as a service employee may do in similar situations (Lengnick-Hall, 1996). Where a client's involvement in creation of service is highly observable, such involvement may serve as a model for other clients to follow. Thus, some clients may be more actively involved in service production processes than the regular employees (Mill \& Morris, 1986).

\section{THE THROUGHPUT STAGES}

The throughput stage is where inputs are operated upon and transformed into outputs. In contrast to goods-producing organizations, the customers of a service firm become part of the system. For instance, the clients of a fitness club need to be in the premises, and participate in the production of the services offered by the firm.

From a different perspective, the throughput stage is the service experience itself and is shared by the customer and the organization (Cusins, 1994). Most researchers in service literature have used the term "service encounter" to designate the throughput stage in service delivery system (e.g., Bitner, 
Booms, \& Tetreault, 1990). Service encounters, in the broadest sense, are defined as the direct interactions between a service firm and its clients and face-to-face interactions between the employee and the client. Of the several factors that influence the perceptions of service quality, the experiences in the service encounter seem to be the most dominant influence (Bitner et al., 1990).

While it is generally true that the interface between the service provider and the client is the essence of a service encounter, we must acknowledge that there are other types of contacts between a service firm and clients during service encounters including customer contacts with physical environment and other customers. These three types of contacts in the service encounter-contacts with employees, physical environment, and other customers are critical to health/fitness clubs.

\section{Contact with Employee}

In line with most researchers, Suprenant and Solomon (1987) defined the service encounter as "the dyadic interaction between a customer and service provider." (p.87) The focus here is on the interpersonal element of service firm performance. In fact, customers' contact with employees in service encounters takes center stage in a service operation for three main reasons. First, intangible character of the service makes it difficult to be measured, thus customers do view the encounter with the service employee as a unique and distinct component of a service. Second, employee contact in the service encounter is significant because of service employees' role as the linking pin between the service organization and its market. In systems terminology, the service employees are the boundary spanners for their organization. The third reason flows from the former two, and it relates to perceptions of service quality. Of the several factors that influence the perceptions of service quality, employee-client contact in the service encounter seems to be the most dominant influence (Suprenant \& Solomon, 1987). 


\section{Contact with Physical Environment}

Bitner (1992) refers to the physical environment in service firms as "servicecape" and classified servicecape into three dimensions - ambient conditions, spatial layout and functionality, and signs, symbols, and artifacts. Bitner (1992) further argued that "physical environment provides a visual metaphor for an organization's total offering; the servicecape has a facilitator role by either aiding or hindering the ability of customers to carry out their respective activities; and the physical environment can serve as a differentiator in signaling the intended market segment, positioning the organization, and conveying distinctiveness from competitors" (p. 67). The servicecape is even more significant in fitness/health services as their production and consumption of these services are largely dependent on the customer use of the facilities and equipment. In other words, apart from providing cues about the expected level of service, the physical environment can affect the actual delivery of the service.

The effect of physical environment (or servicecape) might have great influence on consumers' perception of the service. Not only can physical environment play an important role in providing cues about the expected level of service but also can affect the actual delivery of the service. In a health/ fitness club, for example, pleasant surroundings such as fresh air, music, and/or interior design communicate different level of performance than a crowded and messy environment. In addition, arrangements of equipment such as free weights and cardiovascular exercise machines can affect members' perception of service delivery, especially if members are concerned about safety.

\section{Contact with Other Customers}


Service organizations should take an action to prevent any problem situation caused by customers. Failure to do this quickly and efficiently may seriously damage the impression that other customers have of the service (Lovelock, 1996). In service organizations including fitness clubs, "employees can also be taught to recognize characteristics of situations and anticipate the moods of their customers so that some potential problem situations can be avoided completely or alleviated before they accelerate." (Bitner, Booms, \& Mohr, 1994; p. 102). Therefore, organization should inform prospective customers in advance about the specific nature of a service, and the behavioral expectations for the customers. This practice is what Schneider and Bowen (1995) call a "realistic service preview" which provides the customers with a clear picture of the role they will play in service co-production.

\section{THE OUTPUT STAGE}

In service systems, the output stage refers to the results from the service encounter derived by both the organization such as profitability and customer retention, and the customer such as changes in 
customers' mental and physical states (Grove \& Fisk, 1992). The significant output in our conceptualization is the quality of fitness services. While the objective quality of service is critical, most often it is quality as perceived by clients that has been the focus of research. Two contrasting viewpoints are advanced in this regard. A number of authors have concluded that service quality as perceived by consumers stems from a comparison of what they feel service firms should offer (i.e., their expectation) with their perceptions of the performance of firms providing the service (Parasuraman, Zeithaml, \& Berry, 1985). However, both conceptual arguments and empirical results suggest that the gap theory may not be appropriate, and that overall service quality is primarily determined by the service provider's performance (Cronin \& Taylor, 1992).

Chang and Chelladurai (1996) and Chelladurai and Chang (1999) argued that these two differing perspectives may be differentially meaningful in consumer and human services. In consumer services, the client is more likely to be aware of what he/she wants and therefore, his/her expectations for the service may be more definite and correct. Also, because the performance of the provider is simpler and more routinized, such performance may not contribute much to quality perceptions. Other factors such as employee's appearance and cleanliness of facility and/or equipment permit the formulation of clear expectations and more objective evaluation. Thus, the gap theory may be operative here. That is, the customer perceptions of quality will be influenced by the difference between what was expected and what was received.

In contrast, a customer may not have clear expectations about the human service. When an individual goes to a medical practitioner (a human service provider), for example, the patient may know the location and intensity of the pain but may not have any clue as to what causes it, the remedy for it, and/or how the remedy should be administered. To the extent the patient is ignorant of these critical elements of the service, he/she can not form any expectation or the service except the hope that the pain 
will go away. In human services, employees' professional knowledge/skill, performing promised service and willingness to help customers be-come more important. Under these circumstances, the performance theory of quality perceptions will be more relevant.

\section{THE OUTCOME STAGE}

The quality of service as an output of the system leads to several outcomes for the customer, employee, and/or the organization. As our concern here is with generation of quality in fitness services, we focus on the reactions of the client and the employee to their experiences in the service encounter (throughput stage) and their perceptions of the quality of service just produced (output stage).

\section{Client Satisfaction}

A significant emphasis placed in the literature on service management is that a satisfied customer is likely to continue to buy the service again and again. It has also been suggested that the sense of satisfaction a customer gains is largely a function of perceived quality of the service received. As noted earlier, perceptions of quality could be either on the basis of the discrepancy between client's expectations and his/her perceptions of service received or on the basis of perceptions of absolute performance. Irrespective of the sources of quality perceptions, if the client/customer perceives quality in the service, he/she will be satisfied and turn out to be a repeat customer. The essential point here is that perceptions of quality is the driving force behind client satisfaction and subsequent purchases of that service, and such perceptions of service quality are largely derived from the experiences in the service 
encounter. In addition, client's own attitudes and behaviors that were perceived to be instrumental to a positive service encounter are likely to be reinforced and be exhibited in subsequent encounters.

\section{$\underline{\text { Employee Satisfaction }}$}

Our model places equal emphasis on service employee's satisfaction with the service encounter. It is customary to think of employee satisfaction with the job as a significant organizational outcome. Several theorists have also suggested that increased job satisfaction may enhance member motivation and subsequent performance. Typically, job satisfaction is said to consist of several facets including salary, working conditions, supervision etc. A service employee is also subject to the same influences. However, our emphasis here is on employee's satisfaction with the experiences in the encounter. That is, the focus is on the work itself that is one of the facets of satisfaction emphasized by almost all conceptualizations of job satisfaction. In fact, scholars such as Herzberg (1968) and Hackman and Oldham (1976) isolate the work and its attributes as the source of motivation and satisfaction in a job. Motowidlio (1984) found a significant relationship between employee satisfaction and work behaviors that reflect interpersonal sensitivity and kindness toward others--behaviors that would seem necessary for acting out a customer service orientation. Bowen and Howell (1990) also found that employee satisfaction is associated just as much with the positive feelings employees receive from customers they serve as it is with anything they receive from their own supervisors. Following this line of reasoning, we suggest that the greater satisfaction the service provider has with the service encounter, the greater the motivation to engage in more fruitful encounters. By the same token, if the encounter was not satisfying, the quality-oriented employee would alter his/her behaviors to enhance the quality of the encounter. Thus, employee satisfaction with service encounters is a significant influence in the creation of quality. 


\section{QUALITY ASSURANCE APPROACH}

The model as outlined above is consistent with quality assurance approach to management of service operations. As customers become more knowledgeable and aware of quality concerns in services, they may overtly or covertly set the standard of quality. By the same token, a customeroriented firm also would be aware of the level of quality that needs to be built into the service operation. However, it is one thing to be aware of the quality demanded in a given context but it is another thing to ensure that such quality is achieved. In other words, if we know the quality of service we want to provide, how do we assure it is delivered? In this regard, a number of authors have introduced the concept of "Quality Assurance." Quality assurance is "all those actions which the service firm takes in order to give confidence that a defined quality of service is being achieved" (British Standards Institute, 1991, p. 1). It must be noted that quality assurance is not the same as quality control. While quality control, employed at the output stage, monitors "the output of the service provided against a specified standard (British Standard Institute, 1991, p. 3). In contrast, quality assurance programs are operative at the input and throughput stages, and they focus on eliminating the causes of recurring quality problems (DiPrimio, 1987). In DiPrimio's view, quality assurance programs must be focused on three significant dimensions of quality--design quality, production quality, and perceived quality. We have superimposed DiPrimio's monitoring of three dimensions into our systems model of quality in fitness services.

\section{Design Quality}

Deming (1986) maintained that $94 \%$ of all failings were caused by built-in system faults such 
as the design of the service, the organization of the company and leadership style. Only $6 \%$ had specific causes such as carelessness, ignorance, bad temper, etc., in the operative and front-line. Thus, designing for quality becomes critical for service operations, and it should be focused on the raw material sent in for processing, and the conversion processes (DiPrimio, 1987). In our model, design quality includes management commitment of quality, communication between management and employees, hiring service oriented employees, and identifying customers' needs. We suggest that design quality can be enhanced through the combined efforts of management, employees and customers.

\section{Production Quality}

As we noted earlier, the actual production of the service takes place at the throughput stage or the service encounter. The service encounter is the central source of perceptions of service quality. Although services are produced based on inputs of management, the service employee, and the customer, customers tend to overlook those inputs and focus on the service encounter (i.e., throughput or production phase) to evaluate the quality of the service offered.

\section{Perceived Quality}

Perceived quality refers to how customers view the quality of the services they have just received. Their perceptions of quality may be influenced by production quality as well as design quality. Perceived quality is measured as an output of the service delivery process. In this stage, customers evaluate whether their needs have been met, and perceive the quality of the service accordingly. 


\section{CONCLUSION}

Within the field of business and industry, service quality has been of considerable interest to researcher, however, the study of quality in sport industry has been limited, especially in the fitness service industry. Given the importance of offering quality services to customers, it is disappointing that more attention has not been paid to the concept of service quality in fitness industry contexts.

This study was conceived to fill the need to understand the dynamics of quality in fitness services. Accordingly, this paper presented the conceptual framework (Figure 1.) applicable to service quality in fitness services by applying system theory. The framework anchoring this paper is based on (a) unique features of fitness services, and (b) customer involvement in the production of a service from the perspective of the input-throughput-output of a system. The most unique feature of fitness services is the agonistic participation of the customer in the creation of the service. While customer participation is generic to all kinds of services, such participation is largely passive in nature. In contrast, fitness services require active and vigorous participation of customers. The second perspective that informed the development of the model was that of a system. Several authors have suggested that service can be broken down into the three stages of a system - input, throughput, output (e.g., Chang \& Chelladurai, 1997; Cusins, 1994; Edvardson et al., 1994; Lengnick-Hall, 1996; Lovelock, 1996; Murphy \& Ross, 1987). In extending this view, Lengnick-Hall (1996) suggested that a customer's role in service production can also be compartmentalized into three stages of a system.

We discussed the contribution of inputs, throughputs, outputs, and outcomes in service delivery system to overall quality perceptions. While systems theory has been discussed in business and educational literature, its use in the service industry has been very limited. Some scholars (e.g., 
Gronroos, 1990) have emphasized that the process in the delivery of service (the way a provider delivers a service) is as important as the output (what finally goes to the customer). However, there have been few studies that emphasize the importance of inputs in the delivery of services.

In this paper, we suggested management, employees, and customers all contribute as inputs to improve quality of services. In addition, physical environment and other customers also influence on customers' perceptions of service quality in throughputs stage of service delivery system. As for clients, Lengnick-Hall (1996) argues that customers not only receive the service, but they also have roles to perform in service operations. In her view, the customers' roles in service production are five-foldthose of a resource, a co-producer, a buyer, a user, and a product. The role of resource relates to the input stage, the co-producer role to the throughput stage, and the roles of the buyer, the user, and the product relate to the output stage.

Given the place of client/customers in the input-throughput-output conception of a service delivery system, the perceptions and reactions of the client/customers to their own roles and to other elements in the three stages of the system become critical. As noted, this view is consistent with the principles of quality and total quality management (TQM). Further, it is also consistent with literature on service quality which underscore the significance of customer perceptions and their reactions to quality element (Berry, Parasuraman, \& Zeithaml, 1994; Parasuraman, Zeithaml, \& Berry, 1991).

Finally, quality assurance approach was discussed to improve quality of service. Finally, it was argued that customers' and employees' satisfaction are based on perceptions of quality of service they delivered and received.

\section{$\underline{\text { Future Research }}$}


The framework anchoring this study is based on (a) unique feature of fitness services, and (b) customer involvement in the production of a service from the perspective of a system. The most unique feature of fitness services is the agonistic participation of the customer in the creation of the service. While customer participation is generic to all kinds of service, such participation is largely passive in nature. In contrast, fitness services require active and vigorous participation of customers. The second perspective that informed the development of the model was that of a system. Several authors have suggested that service can be broken down into the three stages of a system-input, throughput, output (Cusins, 1994; Lengnick-Hall, 1996; Lovelock, 1996; Murphy \& Ross, 1987). In this paper, however, we broke down service delivery system into the four stages - input, throughput, output, outcome - by differentiating customer satisfaction (outcome) from customers' perception of service quality (output).

The existing literature on marketing of services has identified the critical roles of service quality and customer satisfaction in the formation of purchase behavior by consumers. However, the issue is made complex because of the confusion about the distinction between the two constructs, and the causal direction of their relationship. Number of scholars suggested that customer satisfaction is a function of their assessment of service quality, product quality, and price (Cronin \& Taylor, 1992), while others argue that service quality should be positioned as subsequent to satisfaction due to the fact that quality judgement result from satisfying or dissatisfying service encounters (Bitner, 1990; Bolton \& Drew, 1991). In this paper, however, we proposed that service quality is an antecedent of customer satisfaction in the formation of consumers' repurchase intentions. This logic stems from the observation that a customer can be satisfied with a low-quality service encounter if they expect minimal performance. Similarly, dissatisfaction can result from high-quality performance if expectations exceed the maximum potential of a service provider. However, it is necessary to conduct an empirical study to verify the causal relationship between service quality and customer satisfaction as well as the framework developed 
in this study. It will be more informative to verify the relative utility of the framework for academicians as well as practitioners.

\section{REFERENCES}

Ahmed, I., \& Parasuraman, A. (1994). Environmental and positional antecedents of management commitment to service quality: A conceptual framework. Advances in Service Marketing and Management, 3, 69-93.

Babin, B.J., \& Boles, J.S. (1996). The effects of perceived co-worker involvement and supervisor support on service provider role stress, performance, and job satisfaction. Journal of Retailing, 72(1), 57-75.

Beatty, S. E. (1988). An exploratory study of organizational values with a focus on people orientation, Journal of Retailing, 64 (4), 427-452.

Bitner, M.J. (1992). Servicescapes: The impact of physical surroundings on customers and employees. Journal of Marketing, 56, 57-71.

Bitner, M.J. (1990). Evaluating service encounters: The effects of physical surroundings and employee responses. Journal of Marketing, 54, 69-82.

Bitner, M.J., Booms, B.H., \& Mohr, L.A. (1994). Critical service encounters: The employee's view. Journal of Marketing, 58, 95-106.

Bitner, M.J., Booms, B.H., \& Tetreault, M.S. (1990). The service encounter: Diagnosing favorable and unfavorable incidents. Journal of Marketing, 54, 71-84.

Bolton, R., \& Drew, J.H. (1991). A multistage model of customers' assessments of service quality and value. Journal of Consumer Research, 17, 375-384. 
Bowen, D.E., \& Howell, J.P. (1990). Substitutes for leadership: Effective Alternatives to ineffective leadership. Organizational Dynamics, 19(1), 20-38.

Bowen, D.E., \& Schneider, B. (1988). Service marketing and management: Implications for organizational behavior. In B.M. Staw \& L.L. Cummings, Research in Organizational Behavior (eds.), 10, 43-80. Greenwich, CT: JAI Press.

British Standards Institute. (1991). BS5750 part 8: Guide to quality management and system elements for services. Milton Keynes: British Standards Institute.

Chang, K., \& Chelladurai, P. (1997). Determinants of quality in fitness/health services: A systems approach. Paper presented at the 5th Annual Congress of the European Association for Sport Management. Glasgow, Scotland.

Chang, K., \& Chelladurai, P. (1996). A model of service quality in health/fitness clubs. Paper presented at the 11th Annual Conference of the North American Society for Sport Management. Fredericton, New Brunswick, Canada. May 29-June 1, 1996.

Chelladurai, P., \& Chang, K. (1999). Quality in sport services: A framework for analysis and action. Manuscript submitted for publication.

Cronin, J.J., \& Taylor, S.A. (1992). Measuring service quality: A reexamination of extension. Journal of Marketing, 56, 55-68.

Cusin, P. (1994). Understanding quality through systems thinking. The TQM Magazine, 6(5), 19-27.

Deming, E. (1986). Out of the Crisis. Cambridge, MA: MIT.

Dickens, P. (1994). Quality and Excellence in Human Services. NY: John Wiley \& Sons.

DiPrimio, A. (1987). Quality Assurance in Service Organization. PA: Chilton Book Company.

Edvardsson, B., \& Olsson, J. (1996). Key concepts for new service development. The Service Industries 


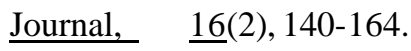

Edvardsson, B., Thomasson, B., \& Ovretveit, J. (1994). Quality of Service: Making It Really Work. New York, NY: McGraw-Hill Book Company.

Garvin, D.A. (1983). Quality on the line. Harvard Business Review, 65-75.

Gronroos, C. (1990). Service Management and Marketing: Managing the Moment of Truth in Service Competition, Lexington Books, Lexington, MA.

Grove, S.J., \& Fisk, R.P., (1992). Observational data collection methods for service marketing: An overview. Academy of Management of Marketing Science, 20, 217-224.

Hackman, J.R., \& Oldham, G.R. (1976). Motivation through the design of work - Test of a theory. Organizational Behavior \& Human Performance, 16(2), 250-279.

Henkoff, R. (1994). Service is everybody's business. Fortune, June 27, 48-60.

Herzberg, F. (1987). One more time: How do you motivate employees? Harvard Business Review, 65(5), 109-120.

Hogan, J., Hogan, R., \& Busch, C. M. (1984). How to measure service orientation, Journal of Applied Psychology, 69(1), 167-173.

Jackson, S. E. (1983). Participation in decision making as a strategy for reducing job-related strain. Journal of Applied Psychology, 68, 3-19.

Johnson, R.L., Tsiros, M., \& Lancioni, R.A. (1995). Measuring service quality: A systems approach. Journal of Service Marketing, 9(5), 6-19.

Lengnick-Hall, C. (1996). Customer contributions to quality: A different view of the customer-oriented firm. Academy of Management Review, 21(3), 791-824.

Lovelock, C.H. (1996). Service Marketing (3rd Edition). NJ: Prentice-Hall. 
Lovelock, C.H. (1991). Service Marketing (2nd Edition). NJ: Prentice-Hall.

Mills, P.K. \& Morris, J.H. (1986). Clients as "partial" employees of service organizations: Role development in client participation. Academy of Management Review, 11(4), 726-735.

Motowidlio, S. J. (1984). Does job satisfaction lead to consideration and personal sensitivity? Academy of Management Journal, 27, 910-914.

Murphy, P.E., \& Ross, S.C. (1987). Evaluating service firms: Approaches with policy recommendations. Journal of Consumer Policy, 10(4), 363-381.

Parasuraman, A., Berry, L.L., \& Zeithaml, V.A. (1991). Perceived service quality as a customer-based performance measure: An empirical examination of organizational barriers using an extended service quality model. Human Resource Management, 30(3), 335-364.

Parasuraman, A., Berry, L.L., \& Zeithaml, V.A. (1985). SERVQUAL: A multiple item scale for measuring consumer perceptions of service quality. Journal of Retailing, 64, 13-37.

Rizzo, J. R., House, R. J., \& Sidney, I. L. (1970). Role conflict and ambiguity in complex organizations, Administrative Science Quarterly, 15, 150-163.

Schneider, B. (1990). The climate for service: Application of the construct. In B. Schneider.

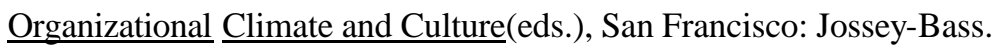

Schneider, B. and Bowen, D. (1995). Winning the Service Game. Harvard Business School Press. Boston, MA

Schneider, B., Wheeler, J.K., \& Cox, J.F. (1992). A passion for service: Using content analysis to explicate service climate themes. Journal of Applied Psychology, 77(5), 705-716.

Schneider, B. and Bowen, D. E. (1985). Employee and customer perceptions of service in bank: Replication and extension, Journal of Applied Psychology, 70, 423-433. 
Spencer, B.A. (1994). Models of organization and total quality management: A comparison and critical evaluation. Academy of Management Review, 19, 446-471.

Surprenant, C.F., \& Solomon, M.R. (1987). Predictablility and personalization in the service encounter. Journal of Marketing, 51, 86-96.

Zeithaml, V. A., Berry, L. L. \& Parasuraman, A. (1988). Communication and control processes in the delivery of service quality. Journal of Marketing, 52, 35-48. 